\title{
Inguinal Bladder Hernia: A Case Report
}

\author{
Brano Djenic ${ }^{1 *}$ and Kaveh Homayoon ${ }^{2}$ \\ ${ }^{1}$ General Surgery Resident, Department of Surgery, Maricopa Medical Center, USA \\ ${ }^{2}$ Department of Surgery, Division of Urology, Maricopa Medical Center, USA
}

Submission: April 26, 2017; Published: May 05, 2017

*Corresponding author: Brano Djenic, Department of Surgery, Maricopa Medical Center, Phoenix, AZ 85008, USA, Tel: 2108630673; Email: brano.djenic@mihs.org

\section{Introduction}

Groin hernias have various sac contents. From vermiform appendix and acute appendicitis to ovaries, fallopian tubes and urinary bladders, hernia contents can greatly differ [1-4]. The term" scrotal cystocele" was first proposed by Levine in 1951 to describe an inguinal-scrotal bladder hernia [5]. Herniation of the urinary bladder is not rare. Literature reports that about $1-3 \%$ of all inguinal hernias involve the bladder, more commonly in males over 50 years of age [6]. We are presenting a case with a bladder hernia as a relatively rare entity, its unique presentation, for general awareness in hernia surgery and although nonoperative, for its management.

\section{Methods}

This is a case report and a review of the literature. This case study was reviewed and approved by IRB. Diagnostic work up and follow up care were carried out at Maricopa Medical Center, in Phoenix, Arizona, USA.

\section{Case Presentation}

The patient is a 77 year old man with Parkinson's dementia, chronic urinary incontinence, aortic stenosis, hypertension and hyperlipidemia who was initially evaluated by an urologist in the emergency department and found to have lower urinary tract symptoms (LUTS), urinary tract infection (UTI) and bilateral hydronephrosis in addition to a right-sided inguinal bladder hernia (IBH) on imaging (see below). Due to presence of bilateral obstructive uropathy secondary to bladder outlet obstruction, a Foley catheter was paced which resolved the bulging scrotal swelling. The UTI was treated with appropriate antibiotics. Following treatment of UTI, the patient was followed in clinic; after a discussion of the risks and benefits of the surgical procedure with the family, the patient was offered non-operative management due to multiple co-morbidities, dementia and functional status. Patient is followed in the clinic every month for management of his Foley catheter. He remains asymptomatic (Figure 1-3).
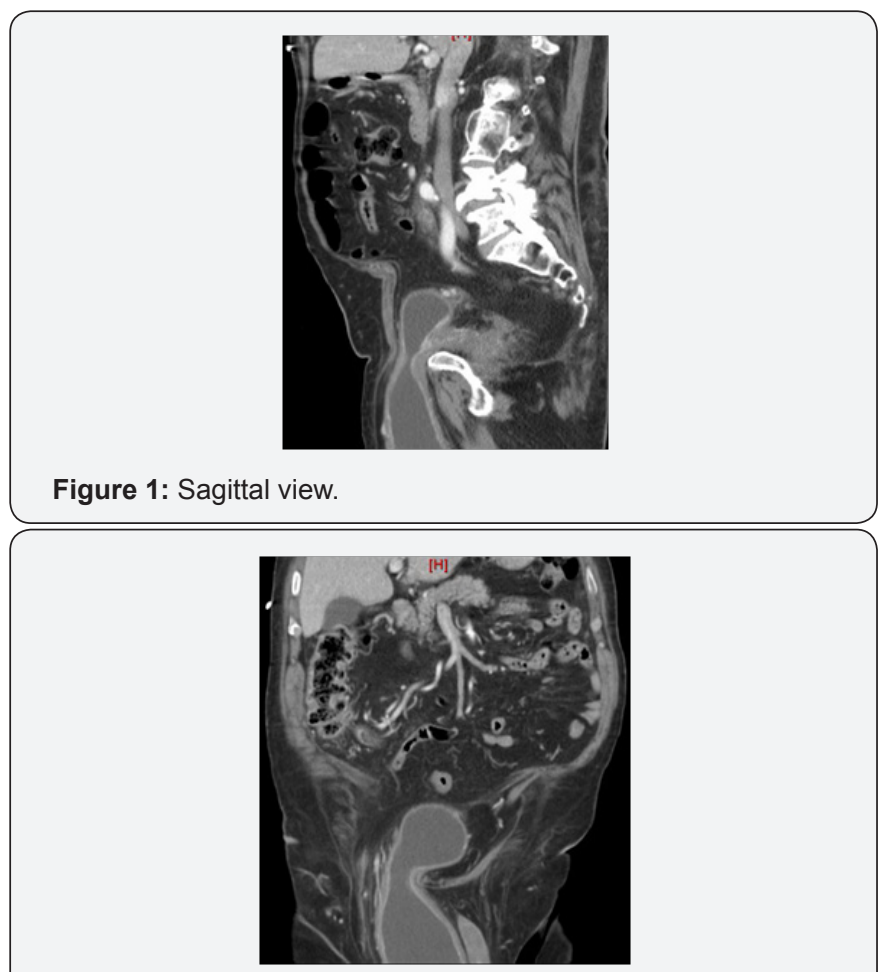

Figure 2: Coronal view.

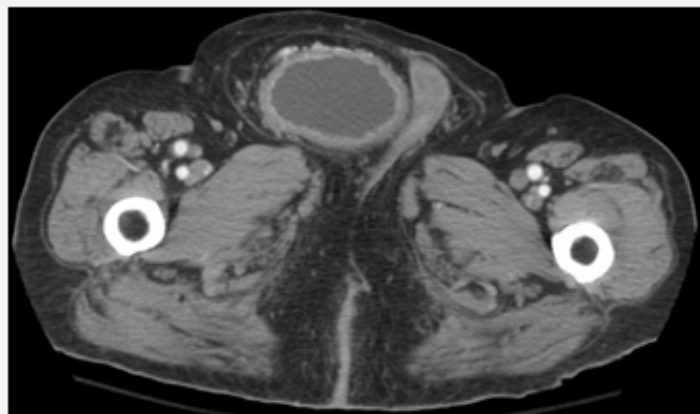

Figure 3: Transverse view. 


\section{Discussion}

Most bladder hernias involve the inguinal and femoral canals, with the latter more frequent in women, and a predilection for the right side has been reported [6]. Any portion of the bladder may herniate, from a small portion or a diverticulum to most of the bladder, as observed in our case. Bladder hernias have been classified into three types according to their relationships with the peritoneum: paraperitoneal, the most frequent type, intraperitoneal and extraperitoneal hernia. Anatomically, just like typical groin hernias, inguinal bladder hernias may be classified as indirect or direct, dictated by its relation to the inferior epigastric vessels [6]. Most bladder hernias are asymptomatic and discovered incidentally during surgery or seen on imaging for unrelated reasons. LUTS are most commonly the initial complaints. Patients with large hernias may have specific symptoms, such as decrease in size of the hernia after micturition, or the two-stage micturition, in which the patient initially empties the normally located bladder, then voids again after manual compression of the hernia sac to push urine out [7].

Variety of surgeons repair inguinal hernias. However, in the setting of males over 50, those with recurrent hernias, obese males or males with LUTS, modified approach should be considered - pre-operative imaging and urological consultation - in order to avoid serious iatrogenic bladder injuries. Weather anticipated or discovered during a routine herniorrhaphy, most asymptomatic bladder hernias can be repaired at the same time as the hernia repair via the same incision and without resection. However, there exist instances in which resection is indicated: cancer in the herniated bladder, tight neck of the bladder hernia, true herniated bladder diverticulum or necrosis of the bladder wall [7]. In such cases, multidisciplinary approach, including urologists, general surgeons and radiologists, is recommended for optimal management. At any time that IBH is suspected, anticipation is perhaps the most important factor in minimizing potential injuries. Involving other experts is always advised when uncertainty exists.

\section{References}

1. Ozkan OV, Semerci E, Aslan E (2007) A right sliding indirect inguinal hernia containing paraovarian cyst, fallopian tube, and ovary: a case report. Arch Gynecol Obstet 279(6): 897-899.

2. Breitenstein S, Eisenbach C, Wille G (2005) Incarcerated vermiform appendix in a left-sided inguinal hernia. Hernia 9(1): 100-102.

3. Gurer A, Ozdogan M, Ozlem N (2006) Uncommon content in groin hernia sac. Hernia 10(2): 152-155.

4. Isaacs LE, Felsenstein $\mathrm{CH}$ (2002) Acute appendicitis in a femoral hernia: an unusual presentation of a groin mass. J Emerg Med 23(1): 15-18.

5. Levine B (1951) Scrotal Cystocele. JAMA 147: 1439-1441.

6. Bacigalupo LE, Bertolotto M, Barbiera F (2005) Imaging of Urinary Bladder Hernias. American Journal of Roentgenology 184(2): 546-551.

7. Moufid K, Touiti D, Lezerek M (2013) Inguinal Bladder Hernia: Four Case Analyses. Rev Urol 15(1): 32-36.

Your next submission with Juniper Publishers will reach you the below assets

- Quality Editorial service

- Swift Peer Review

- Reprints availability

- E-prints Service

- Manuscript Podcast for convenient understanding

- Global attainment for your research

- Manuscript accessibility in different formats

( Pdf, E-pub, Full Text, Audio)

- Unceasing customer service

Track the below URL for one-step submission https://juniperpublishers.com/online-submission.php 